\title{
The Urgency of Water for Human life in Science and Al Quran Perceptive
}

\author{
K Yankumara \\ Islamic Building of Jagad Alimussirry Surabaya, Indonesia \\ Email: ganbatteayuma@gmail.com
}

\begin{abstract}
Water being the most important component to life directness in the earth, especially for mankind. Water is not only used for physical needs but also used for spiritual purposes like a purification symbol in Islam. Islam requires its followers to perform ablution (using water) before performing prayers or reading the Al-Quran. In some regions, especially in Java, water is considered sacred because it is used to means of ritual. Water is also being the source of civilization. The water complexity for human life can't be separated from the molecular components are compose it. Some of the medical research was found the water peculiarity as a potion. The another of water peculiarity famous as crystal structures, righteously human, water has an emotional. The water peculiarities were summarized in the Holy Quran and the Science development has given evidence that water is the great miracles Allah SWT has given to mankind, it is not a chance but it is a great management.
\end{abstract}

Keywords: water peculiarity; mankind; great management

\section{INTRODUCTION}

Water is an important component in the survival of the earth, from microorganisms to the most complex living things need water to sustain their life. With the nature created by Allah, humans feel a close relationship between water and life. Water is one of the greatest gifts that Allah bestows on all mankind. With water, Allah revives, spreads sustenance, and creates humans. In QS. Al Anbiya': 30 Allah SWT said:

"And from the water, We made everything that is alive." (Al Anbiya': 30)

Water-life and life-water-inseparable [1]. Approximately $60 \%$ of the cells making up organisms are composed of water as well as its metabolic movements which takes place in solution. Plants also need water for their survival and growth. Plants absorb minerals in the soil through the roots and are distributed to all other parts of the plant using water.
The number of water found on the earth's surface is relatively constant even though the water experiences current movements, circulates due to the influence of weather, and changes shape too [2]. The relative numbers of water are still influenced by the hydrological cycle, all water on the surface evaporates, at a certain height and temperature, a collection of water vapor will fall as rainwater or snow. Some of the water will flow as surface runoff and some of the others will seep in the ground and be stored as underground water. Of the total water on the earth's surface, $97 \%$ is seawater and the rest is freshwater (3\%). As much as $0.18 \%$ of the total freshwater as soil moisture, $11.02 \%$ groundwater, and $11.02 \%$ deep groundwater.

Water not only fulfills human physical needs but also used for spiritual purposes as a symbol of purification or self-cleansing, for the example in Islam. Islam obliges its people to perform ablution using water before 
performing prayers or reading the Quran. Base on Fiqh learning, ablution, or purification is the material discussed at the beginning of the chapter. The purity of the soul and body of a servant is the main requirement to face Allah SWT, as Allah says in the Qur'an, Surah Al Baqarah: 222, "Indeed, Allah loves those who repent and loves those who purify themselves". (Al Baqarah: 222)

In some areas, especially Java and its surroundings, water is considered holy because it is used as a means of rituals, both for cleansing or purifying oneself (bathing in flower water) and for heirloom objects (jamasan) and the naming of water also appears with several terms that are differentiated according to their respective meanings. -Each, especially in the life of the Javanese people, water or Banyu, toya, way / wai (Old Javanese) is also called tirta (udhaka, Sanskrit) [3]. Apart from being a symbol of holiness, water is also a source of civilization.

Some of the earliest civilizations emerged where water was the most important element in its environment and a challenge to human ingenuity. The Egyptians created a calendar of 365 days in response to the annual floods of the Nile. The Babylonians, who were among the most famous legislators in ancient times, drafted various edicts to regulate the use of water. Water inspired the Chinese to dig a 1,600-kilometer canal, a complex system which after nearly 2,500 Years is still partly in use and still earns the respect of engineers [4].

As a chemical substance, water has unique properties. Water is a very stable compound, an amazing solvent, and a powerful source of chemical energy. Water is away from most organic gases, but is strongly attracted by most inorganic materials, including water itself; in fact, water molecules are more attached to each other than certain metal molecules [5].

It is scientifically known that all liquids increase in density as they cool down until they become frozen. Water "comes out" of these rules when it approaches freezing temperature. It is the reason that the water will increase in density if it gets colder and reaches its lowest level, which is $4^{0}$ Celsius. The density will immediately decrease with the increase in volume when water freezes at a temperature of $0^{0}$ Celsius [6].

This exception is a form of God's extraordinary power, if only the density of water is subject to the laws that apply in nature then within a certain period of time all frozen water (ice) in the oceans will become heavy and sink to the seabed and will remain frozen when the temperature warms up. The Greatness and Care of Allah when it freezes and increases in volume, the water becomes light and floats on the surface of the sea, lake or other and protects the water underneath from getting cold and freezing. Several medical research results also found the privileges of water as medicine.

Dr. Fredon Backman Gledic was the first person in medical history to find evidence of a crisis in the body when dehydrated, because the body always demands water intake. This evidence is an indicator that dehydration can lead to various health problems, such as asthma, diabetes (diabetes), high blood pressure (hypertension), and various inflammation or infections [7]. Another feature of $\mathrm{H} 2 \mathrm{O}$ is that it can form crystal structures known as crystal structures, as if water also has human emotions. Water tries to be beautiful water crystals and the crystal image carries an extraordinary message. Water tries to speak something to us.

Water, basically, is trying hard, bravely, to be a "clear water! I want to be clear water!"... Picture of crystallized may deviate sighly from the information given by modern scientific water analysis [8]. Different places have different crystal structures. Places that are relatively safe from war will have a more beautiful crystal structure than areas that are experiencing conflict. Likewise, in a dirty and clean place, the crystal forms will also be different. Human emotions will also have an influence on the formation of water crystals. 
Some of the features of water have been summarized in the Holy Koran, while scientific developments have increasingly proven that water is an extraordinary miracle given to humans by Allah SWT and that this is not a coincidence but an order and arrangement of the Most Great. Without this extraordinary arrangement of water it would be impossible for life to exist on earth.

\section{A. Water According to Science and Al Quran}

The human body water plays a role as much as $70 \%$, this shows that water is very important for the human body. In everyday life, humans need water to drink, even so that human health is able to be well maintained, so humans are advised to drink 2.5-3 liters of water per day so that the circulation of fluids in the body can be optimal so that there is no deposition of toxins or harmful substances. others in the body. In other words, water in the human body can function as a cleanser from disease.

In some areas, especially in Java and its surroundings, water is considered sacred because it is used as a ritual means, both for cleansing or purifying oneself (bathing in flower water) and for heirloom objects (jamasan). Even in religion water is also a symbol of self-purification. For example in Islam, water is used for ablution before performing prayers; In Catholicism, water is used for baptism. these examples illustrate that water is used as a symbol of cleansing or cleansing from defilement or of everything that is impure [9].

For the Java people, water also plays a role in maintaining the balance of the macrocosmic and microcosmic concepts, where this concept affects the attitude of individual human life to maintain balance and harmony in world life.

Water is the main element in the creation of protoplasm, or what in Arabic is called 'jiblah', which is the living matter found in the cells of plants and animals. The human blood is $85 \%$ water, the kidneys are $82 \%$ water, the muscles are $75 \%$ water, the brain is $74 \%$ water, the heart is $69 \%$ water, and the bones $22 \%$ water [10]. Water is one of the results of the digestive process in the human body. In human life, the average person consumes 60,600 liters of water. In developed countries, the amount of water usage needs per individual reaches 260 liters per day. In detail, 11 liters of water is used to remove metabolic waste in the body, 150 liters of water is used for bathing, 38 liters of water is used for washing, and 115 liters for automatic washing (vehicle / car) [11].

The human body will be dehydrated if it lacks water and can trigger various health problems such as asthma, diabetes, high blood pressure, and other inflammatory diseases (infections). Water, in historical records, has been used by humans to treat various diseases, wounds, and infections such as was used during the civilizations of Ancient Egypt, Babylon, Assyria, Persia, and China. Until now, humans still use water as alternative medicine.

According to Dr. Douglas Louis said that treatment using water is carried out through the stages of hot water, cold water, and warm water. Each water has its function such as hot water which can relax the body, while cold water can generate vitality, passion, and enthusiasm. Meanwhile, warm water can be a catalyst for the adrenal glands and hearing, and can also reduce fatigue and boost the performance of the body's organs. Hot water also is used to relieve symptoms of intestinal spasms and vice versa if the person's intestines feel weak, cold water can help to strengthen them.

In the food chain system that exists in nature, humans are the final consumer level in which plants are the only producers in this system. In the process of producing food that is then consumed by animals or advanced consumers, including humans, plants also need water to survive and reproduce. So it is clear that without water, plants will not survive, so consumers at the next level will certainly 
"become extinct" including humans because there is no more food to eat. Water is the foundation of life, a person can be threatened with death if within 48 hours they do not get water or fluids in their body. Blood, lymph, and fluid in the spinal cord are the most watery parts of the body and are the site of all the chemical and physiological processes of the body. While in the mother's womb, for 9 months humans are in the amniotic fluid. When born into the world, the percentage of water in the human body reaches $75 \%$ of its body weight. When he starts growing up, the water content in the body becomes $60 \%$. By the time a person reaches old age, his body is $50 \%$ water [12].

\section{B. The Opinion of Science and The Holy Quran on the Urgency of Water for Human Life}

Water is a compound of two Hydrogen atoms from the Alkali Group and one Oxygen atom from Group VI A in the Periodic Arrangement of the chemical elements. This compound produces a chemical compound formulation in the form of $\mathrm{H} 2 \mathrm{O}$ and is commonly called water. The presence of hydrogen bonds in water molecules causes a force called cohesion. This cohesion force is needed to counteract forces from outside the molecule breaking hydrogen bonds. This cohesion force occurs at the boundary between water and air to form a "skin" on the surface of the water. This "skin" is strong enough to support small objects, a force called surface tension [13]. Water has the highest surface tension, allowing the association of organisms that live below and above it.

The temperature density of the water is extraordinary. Water has a strange behavior in forming ice, water is lighter in a solid-state than in liquid form so that water floats when it is solidified (ice). At a temperature of $40 \mathrm{C}$ the density of water will decrease or decrease. Car engines take advantage of this water property to become coolant. And one of the other benefits of water's unique properties is that it maintains the temperature in the oceans, allowing for a variety of life in the sea.

Water is almost capable of dissolving all organic substances so that water is said to be a multipurpose chemical solvent. Water can also act as a medium or intermediary in various chemical reactions. Without the dissolving nature of water, the provision of nutrition cannot take place: all living organisms depend on water to dissolve the substances they eat. Plant roots cannot absorb food in the soil unless it is a solution, and human food must be dissolved before it can enter the blood circulation [14].

In the water compound, it is clear how Allah is the Almighty God and is very extraordinary in creating the natural order in the universe in a very orderly manner. Hydrogen is one of the chemical elements that can ignite quickly and oxygen is the element that helps accelerate the hydrogen flame, provisional the water is a selenium compound of the two elements which used to extinguish the fire. The combination of two hydrogen atoms and one oxygen atom to form water $\left(\mathrm{H}_{2} \mathrm{O}\right)$ is a very sturdy molecule [15].

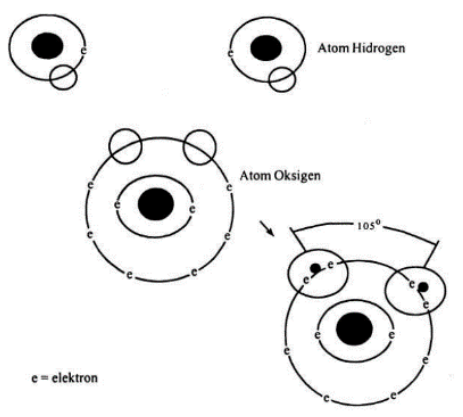

Picture 2.1 The molecular structure of water is formed by combining one oxygen atom and two hydrogen atoms. (Source: Susana, 2003: 20)

Water has other peculiarities, that rise automatically, that called the capillary force, without the capillary strength, the food circulation for plants will stop in the soil, as well as in humans, the capillary strength helps the body's vital processes, namely blood circulation. 
Water, which often appears to follow its own set of natural laws, has the oddest behavior when it forms ice. One reason is that, unlike other compounds, water is lighter in its solid form than as a liquid. As a result, the water floats if it freezes. If this had not happened in nature and ice was heavier than water, it would have continued to sink to the bottom, so sunlight would not be able to melt it. Gradually the pile of ice will accumulate higher and higher until finally all the oceans, rivers and lakes in the world will become solid and rigid [16].

Even when it changes from liquid to solid, water acts contrary to expectations. First it follows a general cooling pattern, that is, shrinking, thickening and solidifying. But when it cools below $40 \mathrm{C}$, the water begins to expand, get lighter and less dense. The cause of this strange change lies once again in the hydrogen bonds between the water molecules. When the water cools, the molecules slow down and begin to squeeze. When the temperature of $00 \mathrm{C}$ is reached. These bonds stop the motion of all molecules and place them at tenuous distances in the light ice crystal [17].

Water absorbs a very large amount of heat without boiling. In this way the large and oily waters can overcome large temperature differences by absorbing heat on hot days and releasing heat on cold days. In places that contain only a small amount of natural water, such as in the desert, temperatures can range from $600 \mathrm{C}$ which burns far below the freezing point at night [18].

Before the temperature of a substance can be raised, all its molecules must be moved in order to move fully. But in water molecules the grip of the strong hydrogen bonds must be loosened first - a task that requires a large amount of heat. If the hydrogen bonds had not held such a strong resistance, water would have boiled below the Arctic temperature, and water all over the world would have immediately evaporated [19]. The ability of water to boil slowly is one of the unique factors (uniqueness) of water apart from those previously stated.

Science pays full attention to water. Water can dissolve most of the food. Water also carries food extracts to various parts of our body. Water is essential in the process of digestion, balancing energy, maintaining body temperature, and getting rid of toxins [20]. Allah SWT's respect for His creatures called water is evident from His words which mention the word "water" in relation to the "Throne of the Most Merciful God". In the Quran, the word "water" (al-ma ') is mentioned in 63 places. Its contents remind us that water is an extraordinary blessing bestowed by the Almighty Creator on His servants and all of His creation [21]. The number 63 referred to here is that the word water in the Quran is repeated 63 times in 41 letters.

Three important components in the formation of the earth's surface are solid matter, atmosphere, and water. As an important part of natural resources, the quality and quantity of water must always be maintained, both sea water, rainwater and groundwater. Each of these waters contains various mineral components and is very much needed by living things on earth. Seawater in everyday life has a very important role for life, namely absorbing $\mathrm{CO} 2$ (carbon dioxide). Carbon dioxide (CO2) on earth is not only absorbed by plants but also by seawater. In the sea there is a food chain system that functions as a carbon sink. Phytoplankton (algae) is the beginning of this chain, $\mathrm{CO} 2$ is used by phytoplankton for photosynthesis, this compound is obtained / absorbed from the atmosphere. In the next food chain, phytoplankton will be eaten by fish, then fish is consumed by humans as the last consumer in the food chain system on earth.

If humans are able to protect the sea properly, the absorption of $\mathrm{CO} 2$ by sea water will also be preserved so that it will also allow the life in it to be guaranteed. And if sea water 
(phytoplankton) and plants on earth are not able to properly absorb carbon dioxide, what happens is the phenomenon of global warming (Global Warming) will appear. The effects of global warming include making the climate on earth irregular, increasing hot temperatures, increasing the volume of sea level which can be caused by melting ice / icebergs at the poles. Al Quran Surat Fatir [35] verse 12 explains how the role of sea water in absorbing $\mathrm{CO} 2$. In the $\mathrm{Al}$ Quran there are many discussed verses relating to the role of water on earth. In QS. Al Anbiya ': 30 explained that Allah made water on earth as the beginning of life. "And We created all living things from water (QS. Al Anbiya ': 30)"

The Quran Surah Al Anbiya ': 30 clearly gives us the understanding that without water it is impossible for a human being or any other living being to live because water is an essential part of human life, even though the human body is mostly composed of water. Scientists say that $4 / 5$ the surface of the earth where we live is filled with water. The force of gravity is able to hold the stability of water on the surface of the earth so that it does not spill into space as Allah says:"And We sent down water from the sky according to a measure, then We made the water stay on the earth, and indeed We have the power to remove it (QS. Al Muk'minun: 18)".

Humans, animals, and plants around us all drink from river water and other water sources that come from clouds that contain water vapor from the oceans. When the objects and plants are dry, the water contained in them will evaporate back to its original place by taking a thousand and one paths. The steam then returned to clouds, rain, springs, and rivers. Survival is associated with this water cycle at a certain rate of no more and no less [22].

The supply of water to rivers occurs at the level and volume determined by Allah. This balance is also seen in the distribution and return of water to the sea or to the air through various means and the formation of clouds so that the cycle is repeated. If there was no channeling, of course the earth would have been filled with floods which sometimes occur when natural processes in the hydraulic cycle are temporarily stopped. This incident contains wisdom, among others, to remind humans and make them grateful for the balance of the cycle. The sky plays a major role in returning the rain from the clouds to the earth [23].

In Al Quran, Surat Al Mursalat (77): 27 Allah explains that Allah made a high mountain to give us fresh water to drink. As in science, the creation of high mountains with freshwater subsidence is a very extraordinary thing. Cloud friction, especially Stratus clouds, occurs in these high mountains and Stratus clouds are clouds that contain water vapor which when broken will fall as rainwater. Rainwater is considered the purest natural water on earth and is needed by humans. "And We made the mountains high, and We made you drink fresh water?" (QS. Mursalat: 27)

Plants can thrive because of rain and water as in the Word of God Noah (71): 11-12: "Surely He will send down heavy rain from the sky on you. And He multiplied your wealth and your children, and made gardens for you, and made rivers for you "(QS: Nuh: 11-12).

The role of rainwater for plants is very large, so the rivers that God flows on the earth are nothing but for human gardens and rice fields. God has sent down rain with His knowledge, wisdom, and power. Indeed, Allah is the All-Giver of Rezeqi, the owner of a strong power, who gives wealth and children and transforms the barren (arid) land into gardens where springs flow.

C. Description Analysis of the views of Science and the Quran Regarding the Importance of Water in Human Life

Al Quran has previously provided an explanation that water is the main source of life as the Word of Allah in QS. Al Anbiya 'verse 30 before finally science acknowledges that water is the main source of life. Scientists agree that water is a very extraordinary complex compound that under certain 
conditions does not operate according to the laws that apply to the compounds themselves. And because of this deviation, the continuity of life on earth can be maintained.

The explanation of the Koran regarding the creation of water is also intended for humans to think and be grateful for what Allah has given. That no one has the power to create water as Allah created it in all the extraordinary order and precision. With Allah creating water for life on earth, especially humans, making humans think of preserving water on earth so that all their necessities of life can always be fulfilled. Science proves the truths in the Koran regarding the creation of water which is then translated into a scientific methodological description of how water is on earth and how it traveled until then the amount of water on the earth has never decreased at all even though humans have used it.

\section{CONCLUSION}

1. Water is the main source of human life, without water humans will not be able to survive. Apart from being used for daily needs such as drinking, bathing, and the other, water is also used by humans in the medical field as medicine. Water is also a symbol of self-purification for adherents of certain religions such as Islam.

2. Science has scientifically proven that water is an extraordinary complex compound that plays an important role in human life. Al Quran explains that the origin of life on earth came from water.

3. Science be holding water as important because it has scientifically proven that without water, humans will not survive. Through the verses of the Holy Quran that talk about the creation of water, Allah asks people to think and be grateful for the giving that He has sent down by preserving the water resources that exist on earth.

\section{REFERENCES}

[1] Frank R. Spellman, The Science of Water, $2^{\text {nd }}$ (New York: CRC Press, 2007), 1.
[2] Tjutju Susana, "Air Sebagai Sumber Kehidupan”, Jurnal Oseana, Volume XXVIII, Nomor 3 (2003), 17.

[3] Turita Indah Setyani, "Simbolisme Air dalam Teks Tantu Panggelaran", Makalah (Water in South and Southeast Asia: Interaction of Culture and Region $3^{\text {nd }}$ SSEASR Conference, Bali Island, Indonesia, 3-6 Juni 2009), 1

[4] Luna B. Leopold \& Kenneth S. Davis, Air $2^{\text {nd }}$ Edition (USA: Time in Corporated, 1980), 121.

[5] Luna B. Leopold \& Kenneth S. Davis, Air $2^{\text {nd }}$ Edition (USA: Time in Corporated, 1980), 1.

[6] Ahmad Fuad Pasya, Dimensi Sains Al Quran: Menggali Ilmu Pengetahuan dari Al Quran (Solo: Tiga Serangkai, 2006), 141.

[7] Sa'id Hamad, Pengobatan Penyakit dengan Terapi Air (Jakarta: Aksara Qalbu, 2007), 9.

[8] Masaru Emoto, Messages from Water (Tokyo: Hado Kyoishuka, 1999), 18.

[9] Turita Indah Setyani, "Simbolisme Air dalam Teks Tantu Panggelaran", Makalah (Water in South and Southeast Asia: Interaction of Culture and Region $3^{\text {nd }}$ SSEASR Conference, Bali Island, Indonesia, 3-6 Juni 2009), 1.

[10] Sa'id Hamad, Pengobatan Penyakit dengan Terapi Air (Jakarta: Aksara Qalbu, 2007), 8.

[11] Sa'id Hamad, Pengobatan Penyakit dengan Terapi Air (Jakarta: Aksara Qalbu, 2007), 9.

[12] Sa'id Hamad, Pengobatan Penyakit dengan Terapi Air (Jakarta: Aksara Qalbu, 2007), 13.

[13] Tjutju Susana, “Air Sebagai Sumber Kehidupan”, Jurnal Oseana, Volume XXVIII, Nomor 3 (2003), 19.

[14] Luna B. Leopold \& Kenneth S. Davis, Air $2^{\text {nd }}$ Edition(USA: Time in Corporated, 1980), 24

[15] [16] [17] Luna B. Leopold \& Kenneth S. Davis, Air $2^{\text {nd }}$ Edition(USA: Time in Corporated, 1980), 1, 28

[18] [19] Luna B. Leopold \& Kenneth S. Davis, Air $2^{\text {nd }}$ Edition(USA: Time in Corporated, 1980), 1, 30.

[20] Sa'id Hamad, Pengobatan Penyakit dengan Terapi Air (Jakarta: Aksara Qalbu, 2007), 59.

[21] Sa'id Hamad, Pengobatan Penyakit dengan Terapi Air (Jakarta: Aksara Qalbu, 2007), 7.

[22] Ahmad Fuad Pasya, Dimensi Sains Al Quran (Solo: Tiga Serangkai, 2006), 3-4.

[23] Ahmad Fuad Pasya, Dimensi Sains Al Quran (Solo: Tiga Serangkai, 2006), 75. 